Act 1990, and these should be utilised to undertake to examine the future provision of the mental health services. I believe that the clinicians who have an intimate and close understanding of the services are the most appropriate professionals to do this.

KING, D. (1991) Moving on from Mental Hospitals to Community Care. A Case Study of Change in Exeter. London: Nuffield Provincial Hospital Trust.

Poole Hospital

Nunthorpe

Middlesbrough

Cleveland TS7 0NJ

\section{Reporting predictable negative results}

SIR: Korczyn et al (Journal, July 1992, 161, 132) report the negative results of their search for a mutation in the PRNP gene in six patients with bipolar affective illness. If I have understood their letter correctly, their justification for this search was based upon the following logical steps: mutations in this gene have been linked with a familial form of CreutzfeldtJakob disease; this has been demonstrated in Libyan Jews; some patients with Creutzfeldt-Jakob disease have affective symptoms; therefore, Libyan Jews with familial affective disorder should have the PRNP gene mutation.

Studies with negative results are of course scientifically as interesting as those with positive results and sometimes more so. This, however, is more likely when negative results are not as glaringly expected as in this case. The authors do not seem to have been discouraged by their findings and recommend that studies for mutant DNA sequences be performed in sporadic and familial forms of psychosis. I earnestly hope that they will not be testing for all known DNA mutations at random in psychotic patients. If they do, goodness knows how much more journal space will be filled with their negative results!

Section of Old Age Psychiatry

ROBERT HOWARD

Institute of Psychiatry

De Crespigny Park

Denmark Hill

London SE5 8AF

\section{Hypnotising lobsters, etc.}

SIR: I was very surprised that the idea of hypnotising lobsters was thought to be evidence of gullibility requiring further photographic proof (Brooks, Journal, July 1992, 161, 134).
As a young child in rural Ireland I was taught to 'hypnotise' various animals by my mother. My particular expertise was in hypnotising turkeys and geese, for which I gained immense kudos as most of my peers were afraid of them. The technique involved stroking them firmly on the back of the neck, until the head rested on the ground at which point a white line was drawn in front of their heads. I often had dozens of them all over the yard, immobile until either they were moved or a loud noise disturbed them.

One recognised technique for hypnotising young children involves gentle, firm massage as this produces the relaxation and narrowing of attention required for induction.

My interest in hypnosis has continued although I confine my practice to people and my cat, Martha, when she requires calming at the vet's.

The Yews

P. POWER-SMITH

Worrall Road

Sheffield S30 $3 A U$

\section{Stress-induced hallucinations}

SIR: Spivak et al (Journal, March 1992, 160, 412-414) describe stress-induced hallucinations, apparently experienced in clear consciousness, in army recruits who exhibited no other gross psychopathology. Cohen (Journal, July 1992, 161, 130) proposes that these experiences are most likely hypnagogic, a common and familiar source of isolated hallucinations. But I think that it may be a mistake to dismiss these unusual stress-induced experiences in this way.

In a recently completed series of retrospective interviews with 200 healthy subjects, $3 \%(n=6)$ described a single isolated experience of a brief secondperson auditory hallucination, in which they heard a voice speaking to them, in clear consciousness. (No subjects in my series described stress-induced visual hallucinations, except in circumstances suggesting they were in a state of clouded consciousness.) These auditory hallucinations had occurred when the subjects had been faced with stress they regarded as 'severe', for example, life-threatening illness in their child. The words heard related to the concurrent stress. Most subjects described hearing comforting words, for example, "it's going to be all right", but some experienced threatening words such as "you're going to die". None of the subjects had experienced any associated psychopathology except distress in proportion to the perceived stress. None had consulted a psychiatrist around the time of the experience. The 'voices' were variously attributed to communication from God, to ghosts, or to 